\title{
ИЗУЧЕНИЕ УПРУГОЙ АНИЗОТРОПИИ ВЕРХНЕЙ ЧАСТИ РАЗРЕЗА ПО ДАННЫМ МАЛОГЛУБИННОЙ СЕЙСМОРАЗВЕДКИ
}

\author{
И.Ю. Герасимова \\ Горный институт УрО РАН, г. Пермь
}

\begin{abstract}
Аннотация: В рамках изучения свойств верхней части разреза возможно опредление характеристик упругой азимутальной анизотропии. Для расчетов могут быть использованы суммарные временные разрезы, полученные в рамках традиционных малоглубинных исследований. Представлены пространственные распределения коэффициентов анизотропии, выполненные для одного из шахтных полей Верхнекамского месторождения калийных солей.

Ключевые слова: азимутальная анизотропия, трещиноватость, Верхнекамское месторождение калийных и магниевых солей, малоглубинная сейсморазведка, коэффициент анизотропии.
\end{abstract}

В рамках изучения верхней части разреза в условиях Верхнекамского месторождения возможна оценка упругих параметров преобладающей ориентации трещиноватой среды, связанных с анизотропией, т. е. с зависимостью сейсмических параметров от направления исследований. Азимутальная анизотропия упругих свойств проявляется и может быть измерена в изменении кинематических и динамических характеристик отражённых волн.

Одной из двух условных групп, выделяемых в индустрии сейсморазведки для решения указанной задачи, является анализ суммарных данных, в рамках которого разработано большое количество методов и методик обнаружения и расчета трещиноватости. В основу технологических решений положено предположение, что трещиноватость придает породам анизотропию скоростей: вдоль преобладающей ориентации трещин волны распространяются быстрее, чем вкрест. Поэтому на этапе обработки сейсмические разрезы могут быть разбиты по секторам, в зависимости от азимутов направленности профильных линий, по которым происходит последующее сравнение получаемых материалов.

Использование для расчета параметров анизотропии верхней части разреза материалов, получаемых при традиционной для исследований Верхнекамского месторождения технологии высокоразрешающей малоглубинной сейсморазведки, связано с рядом осложняющих факторов:

- неравномерное покрытие площади месторождения сейсмическими наблюдениями, в том числе и в пределах отдельных шахтных полей рудников;

- высокая степень расчлененности рельефа местности. В частности, для изучаемого участка, в пределах которого рассчитывались параметры анизотропии, величина абсолютных отметок высот изменяется от 106 м до 248 м.

- перепад высот дневной поверхности не позволяет (без потери качества получаемых результатов) использовать общее для всей площади значение уровня приведения. Например, в пределах района исследований на этапе обработки данных, полученных при работах на разных участках, используются альтитуды линии приведения, соответствующие $+100,+110,+130$ и +150 м.

- кровля соляно-мергельной толщи, являющейся верхним отражающим горизонтом при интерпретации материалов малоглубинной сейсморазведки, крайне невыдержана по простиранию. Абсолютные отметки границы в области шахтного поля колеблются от -16 м до +128 м.

- мощность пород, залегающих между поверхностью земли и кровлей соляномергельной толщи, представленных четвертичными образованиями и отложениями терригенно-карбонатной толщи, весьма изменчива, и изменяется от 20 м до 200 м (рис. 1а). 
- указанные факторы крайне неблагоприятным образом влияют на характеристики упругих свойств в верхней части разреза, подчиняющихся сложным скоростным законам и формируя изменчивые в пространстве распределения интервальных скоростей (рис. 1б-г).
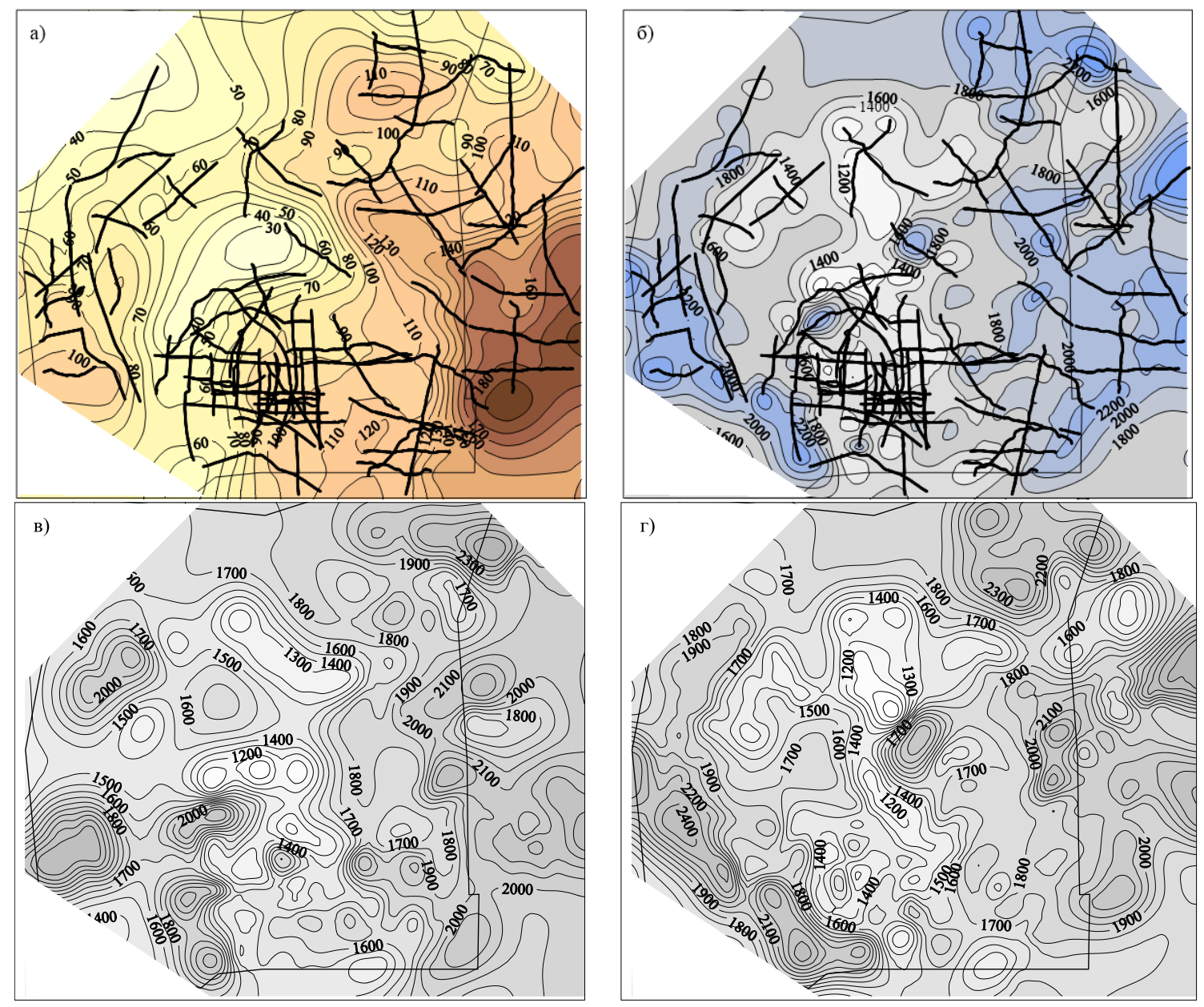

Рис. 1. Характеристики массива пород от дневной поверхности до кровли соляно-мергельной толщи: мощность (а), распределение интервальных скоростей по всему массиву данных (б), по данным субширотного (в) и субмеридионального (г) простирания сейсмических профилей

Таким образом, задача изучения упругой анизотропии значительно усложняется, и может быть на качественном уровне решена с использованием следующей методики:

1. Формирование обобщенного массива интервальных скоростей в толще от уровня приведения до кровли СМТ, включающего материалы, полученные в результате малоглубинных сейсмических исследований вдоль профильных линий, отработанных в период 1996 - 2019 г.г. в пределах участка исследований.

2. Дополнение массива данными, учитывающими абсолютные отметки рельефа местности, положение линии приведения и значения статических поправок, рассчитанных на этапе препроцессинга.

3. Определение осредненного скоростного закона, позволяющего вычислить корреляционные зависимости в скользящем окне, равном 10-метровому интервалу глубин, с учетом изменения альтитуд земной поверхности.

4. Разделение положения участков профильных линий в зависимости от азимутальной составляющей. 
5. Формирование раздельных массивов изменения скоростей, рассчитанных по субмеридиональной и субширотной компонентам.

6. Определение коэффициента анизотропии как отношения максимальных скоростей к их минимальным значениям для интервала глубин от поверхности наблюдения до условной линии с альтитудой 0 м с шагом изменения глубины, составляющем 10 м.

Полученные данные могут быть визуализированы в виде пространственных распределений упругих скоростей и коэффициентов анизотропии (рис. 2).


Рис. 2. Распределение коэффициентов скоростной анизотропии в верхней части разреза: слайс по абсолютной отметке +150 м (a), вертикальный срез с аксонометрической проекцией рельефа кровли соляномергельной толщи (б)

Анализ полученных результатов показывает, что в целом различия величин скоростей Vсю и Vзв на изучаемом участке значительны, но, как правило, не превышают 40 $\%$. При этом коэффициент скоростной анизотропии существенно изменяется как в латеральном, так и в вертикальном направлениях, что, вероятно, является следствием изменчивых геодинамических условий формирования и последующего преобразования толщ пород ВЧР. Величина коэффициента изменяется в приповерхностном слое до 1,84 у.е. и максимальна на отдельных участках вблизи речных долин, пересекающих площадь исследования по различным направлениям (рис. 3). Корреляционной зависимости величины коэффициента анизотропии от абсолютных отметок рельефа поверхности не прослеживается.

При этом с глубиной величина анизотропии уменьшается, что свидетельствует о закономерном уменьшении трещиноватости пород. В частности, на глубине около 50 м от поверхности наблюдения максимальное значение коэффициента анизотропии составляет 1,68 у.е., на глубине 100 м - 1;42 у.е., а на глубине 150 м - 1,31 у.е. Для поверхности, ограниченной абсолютной отметкой 0 м, максимальная величина коэффициента равна 1,14 у.е., что позволяет допустить наличие более плотного массива пород относительно вышезалегающей толщи. Можно предположить, что, вероятнее всего, значительные величины коэффициента анизотропии, наблюдающиеся в приповерхностной толще, характерны для наиболее трещиноватых участков.

В результате обобщения полученных материалов в виде трехмерных массивов, можно осуществлять изучение анизотропных средств верхней части разреза. Этот анализ можно проводить как для отдельных точек среды, так и (непрерывно) для всего объема изучаемых отложений. Подводя итоги, отметим, что изучение упругой анизотропии может, хотя бы на качественном уровне, помочь при решении инженерногеологических задач, свидетельствуя о наличии зон повышенных и пониженных физико-механических свойств пород. 


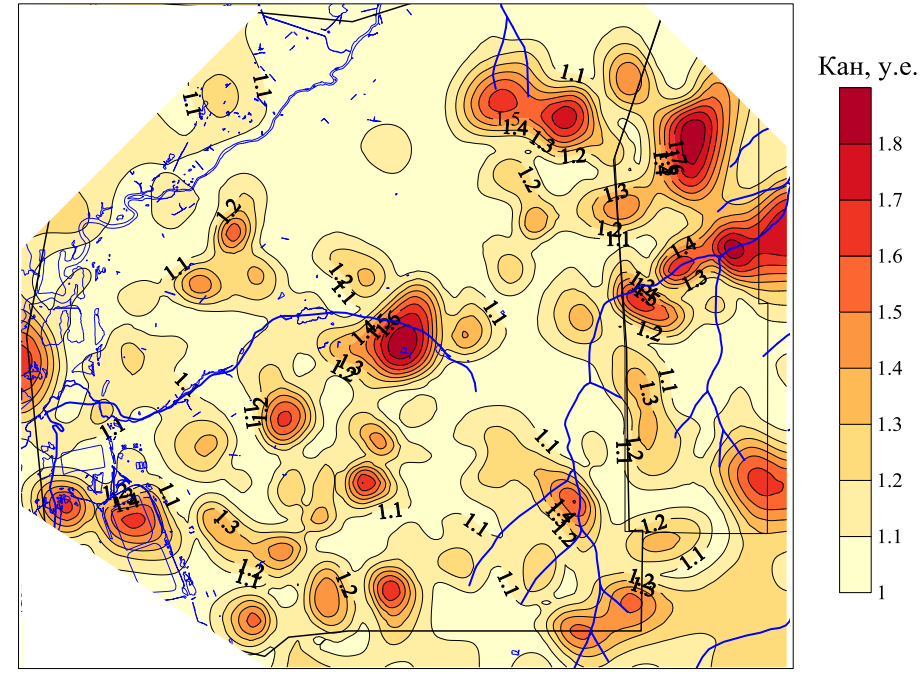

Рис. 3. Распределение коэффициентов скоростной анизотропии в приповерхностной толще пород

\title{
БИБЛИОГРАФИЧЕСКИЙ СПИСОК
}

1. Петротектонические основы безопасной эксплуатации Верхнекамского месторождения калийномагниевых солей / под ред. Н.М. Джиноридзе. - СПб; Соликамск, 2000. - 400 с.

2. Кашубин С.Н. Сейсмическая анизотропия и эксперименты по ее изучению на Урале и ВосточноЕвропейской платформе. - Екатеринбург: УрО РАН. 2001. - 182 с.

3. Кузнецов В.М., Жуков А.П., Шнеерсон М.Б. Введение в сейсмическую анизотропию: теория и практика. - М.: Технологии сейсморазведки, 2006. - 159 с.: ил.

\section{ИЗУЧЕНИЕ ЭЛЕКТРИЧЕСКИХ СВОЙСТВ НАДСОЛЕВЫХ ОТЛОЖЕНИЙ НА ВОСТОЧНО-ТАЛИЦКОМ УЧАСТКЕ ВКМКС}

\author{
М.С. Лучников \\ Горный институт УрО РАН, г.Пермь
}

\begin{abstract}
Аннотация. На примере Восточно-Талицкого участка Верхнекамского месторождения солей показана возможность электроразведки методом вертикального электрического зондирования для изучения и прогнозирования негативных инженерно-геологических явлений надсолевых отложений с целью повышения безопасности горных работ при эксплуатации месторождения. По результатам качественной и количественной интерпретации ВЭЗ выявлена зона пониженных электрических сопротивлений, приуроченной по глубине к отложениям терригенно-карбонатной и соляно-мергельной толщ. Она может быть связана с наличием зон повышенной трещиноватости, по которым происходит активный водообмен, либо с литологическими особенностями пород слагающих разрез.
\end{abstract}

Ключевые слова: электроразведка, удельное электрическое сопротивление, активный водообмен, безопасность горных работ.

\section{Введение}

Метод вертикального электрического зондирования (ВЭЗ) входит в состав комплексных исследований, направленных на обеспечение безопасности ведения горных работ и решения ряда геологических задач на всех стадиях освоения Верхнекамского месторождения калийномагниевых солей (ВКМКС) [1]. На сегодняшний день электрические зондирования остаются одним из самых применяемых электроразведочныХ методов. На основе ВЭЗ разработаны и другие современные технологии - например, электротомография, базирующиеся на тех же принципах, что и для «классических» электрических зондирований. Целесообразность 